\title{
10 health stories that mattered: Mar. 7-13
}

- The federal government announced a \$180-million support package for thalidomide victims. The package includes an immediate $\$ 125000$ tax-free lump-sum payment to all victims, and an additional \$168 million for ongoing costs related to their disabilities. Ottawa later clarified that annual tax-free payments from this pool of funding will cover a wide variety of expenses, including personal support workers, not only medical needs.

- Health Canada received numerous complaints from police over its supervision of medical marijuana users, revealed the Huffington Post Canada. The written complaints, obtained under access to information laws, detailed instances in which police were unable to take action against known drug-trafficking suspects in possession of large quantities of marijuana because the suspects had personal possession licences.

- Quebec health officials confirmed 119 cases of measles in the Lanaudière region, up from the 18 cases first confirmed on Feb. 21. All of the cases are among unvaccinated families and are linked to one child who contracted the virus during a trip to Disneyland in California. Health officials said they expect the number of cases to increase because the child attended school for one day before showing symptoms.

- A survey of 1013 Canadian parents with unvaccinated children revealed that most are still skeptical of vaccines, even after recent outbreaks of measles in Canada and the United States. Despite the fact that measles has regularly been in the news over the past two months, $80 \%$ of respondents said they are "not at all likely" to vaccinate their children. Most cited health reasons $(65 \%)$, as opposed to religious reasons (19\%).

- For the second time in a month, the owners of a Florida naturopathic spa where two Ontario First Nations girls sought alternative treatments for leukemia were ordered by the state to stop practising medicine without a licence. Former employees are also suing the Hippocrates Health Institute, alleging they were fired when they raised concerns about the spa's owners posturing as doctors.

- The British Columbia Ministry of Health is suing the city of Vancouver for payment of health care bills for a man who was hit by a car in the city's Chinatown, according to the Globe and Mail. The province accused the city of "failing to ensure that the sidewalk and roadway were reasonably safe" and "failing to properly maintain trees and shrubs" when Paul Tynes was hit and suffered severe head injury in 2009. Municipalities in BC have paid for part of the medical bills for accident victims since the province passed the Health Care Costs Recovery Act in 2009 to make third parties share ballooning health expenses.

- BC's Island Health Authority suspended three hospitalists for refusing to accept new patients in the midst of a contract dispute. Calls requesting help from hospitalists at Royal Jubilee and Victoria General hospitals were redirected to a third party who said the doctors could not accept new patients because of safety concerns, reported the Times Colonist. An interim deal between Island Health and hospitalists expired in February; new talks are focusing on the number of doctors and how the job is performed.

- The United Nurses of Alberta is suing the province for failing to ensure proper staffing of nursing homes and assisted-living facilities. Under the 1985 Nursing Home Act, such facilities require at least one registered nurse, certified graduate nurse or registered psychiatric nurse on duty at all times.

- A pair of Canadian researchers decried the Chinese-led proposal to put ketamine on the international schedule of psychotropic drugs. University of Ottawa clinical scientist Jason Nickerson and law professor Amir Attaran warned in correspondence to The Lancet that scheduling the drug would deprive most of the developing world of an inexpensive anesthetic and lead to a public health crisis in many countries.

- Canada bid farewell two medical luminaries. Dr. John Evans, cardiologist, founder of Toronto's Medical and Related Sciences innovation centre, and medical education revolutionary, died at his home of Parkinson disease on Feb. 18. Dr. Cy Frank, orthopedic surgeon, CEO of Alberta Innovates-Health Solutions, and chief medical advisor to the Alberta Bone and Joint Health Institute in Calgary, passed away Mar. 5. - Lauren Vogel, CMAJ

CMAJ 2015. DOI:10.1503/cmaj.109-5019 